\title{
THE FOURTH CRUSADE AND THE PROBLEM OF FOOD PROVISION IN THE ACCOUNTS OF ROBERT DE CLARI AND GEOFFROY DE VILLEHARDOUIN
}

This text provides the analysis of two texts, written by Robert de Clari and Geoffroy de Villehardouin, two chroniclers at the times of the Fourth Crusade. The analysis discusses their account of food provision and how Crusaders managed to provide for themselves during their journey from Venice to Constantinople in the period between June 1202 and May 1204.

Keywords: the Crusades, the Fourth Crusade, French chroniclers, Constantinople, provisions, supplies, volume units

doi:10.2478/sho-2014-0006

The problem of army provisions in the Middle Ages has, to a large extent, remained ignored in reference books. However, it does not mean that this problem was not of a crucial importance. The problem becomes even more obscure when we consider the Crusades to Palestine in the years 1096-1291. When we read solely publications written by western and oriental writers who took part in this enterprise, we realize that the description of food eaten by both people and animals, and the ways food was obtained is not only fragmented and incomplete, but sometimes completely absent. In this article I would like to analyse the accounts of two participants of the Fourth Crusade: Robert de Clari and Geoffroy Villehardouin. These accounts are written in the dialects of the Old French language: Picard and Champenois.

The problem of hunger - and, on the odd occasion, prosperity - is discussed in very little detail by the authors of the narratives that describe the Fourth Crusade. These are the accounts of the participants of a Crusade 
not to the Holy Land, but to Constantinople ${ }^{1}$. The first author is a high official and a knight, a marshal from the Champenois region, Geoffroy from Villehardouin (ca. 1148- ca. 1212). His experiences include negotiations with Venetians and envoy to Byzantine Emperors in 1203. When he eventually decided to settle in the newly formed state, the Latin empire, he was the marshall of Romania. His account, La conquete de Constantinople, is considered to be the official account of the mission, but, to a large extent, it is very incomplete ${ }^{2}$. He was one of the so-called "barons" of the Crusade, and yet he mentions the inconveniences of the trip on many occasions. The other account is the account of a poor, Picard knight, Robert de Clari, who died after the year 1215 . He wrote a history under the same title, but in terms of its literary values it is of a much worse quality than Villehardouin's account ${ }^{3}$. However, if we want to get a full picture of the problem of alimentation and provision, his story is very valuable. That is because his story is an account of a regular knight, who struggled with the difficulties known to regular crusaders. At this point his story differs from the story of Geoffroy from Villehardouin.

The Fourth Crusade, initiated by pope Innocent III in 1199, was peculiar, especially when we consider its course and consequences, and when we compare it with the previous Crusades. The political context of the Crusade, which I do not intend to discuss here, meant that the participants were supposed to gather in Venice in the beginning of the summer of 1202. Provision for people and horses was to be prepared in an adequate quantity, and be enough to last for a sea voyage to Egypt or to the Holy Land. People in charge of that were Venetians. They assured they could provide transport for everyone involved, which totaled over 33000

${ }^{1}$ There is a big number of publications on the Fourth Crusade, see: J. Longnon, L'Empire Latin de Constantinople et la Principauté de Morée, Paris 1949; a solid monograph, D. E. Queller, Th. F. Madden, The fourth crusade. The conquest of Constantinople. Second edition. With an essay on primary sources by Alfred J. Andrea, Philadelphia 1997; S. Runciman, Dzieje wypraw krzyżowych, t. 3, Warszawa 1987; Z. Pentek, Cesarstwo Eacińskie (1204-1261). Kolonialne państwo krzyżowców czy Neobizancjum? Poznań 2004, p. 35-69; M. Angold, Czwarta krucjata, Warszawa 2006.

2 Critical edition: Geoffroy de Villehardouin, La conquête de Constantinople, editée et traduite par Edmond Faral..., t. I-II, Paris 1938-1939 [further: Villehardouin]; J. Longnon, Recherches sur la vie de Geoffroy de Villehardouin, suivies du catalogue des actes des Villehardouin, Paris 1939; Z. Pentek, Geoffroy de Villehardouin. Rycerz i kronikarz IV wyprawy krzyżowej, Poznań 1996; Geoffroy de Villehardouin, Zdobycie Konstantynopola, Poznań 2003.

${ }^{3}$ Current critical edition: Robert de Clari, La conquête de Constantinople, ed. Philippe Lauer, Paris 1924 [further: Clari]; Robert de Clari, Zdobycie Konstantynopola, including the list of the chronicle's editions and the literature, p. XXXI-XXXV. 
people and animals. According to the plan, the means of transport was a ship. The route scheduled and the initial course of the Crusade provided a degree of comfort to the crusaders: they would not have to worry about the provision during the journey or occupy themselves with providing their own supplies. These were the terms and conditions negotiated in the spring of $1201^{4}$. Let me discuss now where the participants of the Crusade came from. Their countries of origin were much less diverse than those of the participants of the first enterprise. The crusaders were mainly Franks (from Northern, Central and Eastern France), Venetians, the Lombard and a few Germans. As we can see they came from Central Europe and thus were able to take with them enough food and money to get them to Venice. Upon arrival the Venetians were to take care of provisioning. In the spring of 1202, the crusaders began their preparations to set off. They took only what they considered indispensible for their journey to Venice: weaponry, animals, food and money. The number of crusaders who finally arrived was much lower than expected. It was estimated that 33000 soldiers would appear. A small group who had decided to bear the cross, eventually abandoned the idea of going to Venice with the rest, and decided to go to Palestine on their own without bothering about the fate of the forthcoming crusade. By the way, these were the only crusaders who managed to reach Palestine. The rest of the pilgrims, having arrived to Venice in June 1202 were transported to the island of Saint Nicolas from Lido and waited for the development of the crusade. At first everything seemed to go smoothly. Supplies in Venice provided those arriving with a short stay, but not too long. It soon turned out though that the number of armed pilgrims was a third of what had been expected, and there was no money to pay for the terms of the contract concluded with Henry Dandolo, the Doge of Venice. Firstly, it was Robert de Clari who wrote worryingly that the Venetians had begun to make demands to cover their expens$\mathrm{es}^{5}$. They even threatened not to provide the crusaders with food or water. The chronicler was aware that the behaviour of the Doge and his people was very sensible. Villehardouin precisely states that the food supplies were supposed to last for nine months, both for the people and the animals ${ }^{6}$. There were also, allegedly voluntary, money collections, but this was not enough. As a result, food portions became very small, and some

${ }^{4}$ Villehardouin, chapter 12-28.

${ }^{5}$ Clari, chapter XI.

${ }^{6}$ Villehardouin, chapter 21: "Nos ferons uissiers a passer .iv. .m. et .v. .c. chevaus et .ix. mile escuiers, et es nés .iv. .m. chevaliers et.v. .c., et .xx. mille serjans a pié; et a toz ces 
people must have suffered from hunger. Once there was enough pressure on the crusaders (as a result of food deprivation), the Venetian propaganda started spreading rumours about the prosperous city of Zadar, which, if the crusaders decide to occupy, would be a chance to feed the army. It would also mean that the Venetians could achieve their political goals related to Zadar, which was at the time governed by Hungarians. All that was needed to feed the hungry and to have the financial liabilities covered or delayed was to agree to conquer this Christian city. With no other alternative, the barons of the crusade had to agree to conduct a military action in Zadar. The city was conquered in the middle of November 1202 , and that is where the winter was spent. It is the access to food that was behind this decision ${ }^{7}$. According to Robert de Clari, it was in Zadar where it turned out that the Venetians were practically unprepared for the journey - food supplies were not big enough to last for nine months, as the size of the army was larger than planned ${ }^{8}$. The crusaders were out of money as they had spent it for the collections and food during their unfortunate stay in Venice. So, either Robert de Clari was not very well informed on the subject of provisioning, or the Venetians did not prepare well enough. During their stay in Zadar there was also a bloody fight between the crusaders and the Venetians. What the ground of the conflict was remains unknown. The possible reasons are the distribution of spoils and provision for the nearest future. One more, completely unpredictable factor was that the course of the Crusade changed (to Constantinople, instead of the Middle East). In January 1203, a rumour spread in the crusaders' camp. Alexios IV, a young Byzantine prince, a son of the overthrown, captured and blinded Isaac II made some promises. He promised the crusaders military and financial support in the Holy Land if they helped him retrieve the throne in Constantinople. These were, in fact, just promises the young man was completely unaware of the financial condition of the

chevaus et ces genz iert telx la convenance que il porteront vïande a .ix. mois. Tant vos feromes al mains, en tel forme que on donra por le cheval .iv. marc et por l'ome .ii."

7 Villehardouin, chapter 86: “...et ceste ville si est mult riche et mult bien garnie de toz biens."

8 This fragment in the chronicle of Robert de Clari is somehow undermined though it might be the evidence that the Venetians were not as prepared for the journey as they had declared, or that the stocks ran out sooner than expected, Clari, chapter XVI: “... qu'il ne pooient mie aler en Babyloine, ne en Alixandre, ne en Surie, car il n'avoient mie viandes ne avoir dont il y peussent alerm car il avoient ja pres de tout despendu, que ens u sejorner qu'il avoient fait, que ens u grant loier qu'il avoient donné au navie." 
Byzantium Empire, and how he could possibly fulfil these promises ${ }^{9}$. In April 1203 a huge fleet started heading towards Constantinople, stopping for very practical reasons at the islands in the Adriatic Sea and other reservoirs. The reason for these frequent stops was to search for food ${ }^{10}$, like the well-stocked island of Corfu. Another issue that the chroniclers touch upon was the constant search for water. It is important to mention that over a thousand horses were also transported, and they required proper care, food and water. Villehardouin, very practical and far-sighted man, mentions, whenever he can, the problem of stocking up for the purpose of the trip ${ }^{11}$, and for the purpose of immediate consumption. Extracts about gathering food for the army (probably not by the means of purchase but by confiscation) repeat twice as often in the part describing the eve of the Constantinople siege, which is from the end of June to July 1203. In July 1203, during the siege, the crusaders did not have many options when it came to food acquisition, as it was only permitted to leave the camp at a distance equal to "a crossbow shot length".

Therereally musthavebeen very littlefood. According toVillehardouin's estimates, it was only enough to meet the needs of the besiegers for three weeks. Flour and pork fat were scarce, and fresh meat was only available to those knights who killed their horses, not to the regular crusaders ${ }^{12}$. On July 17, 1203, when the city was conquered people celebrated, but mainly they ate ${ }^{13}$. The crusaders continued to struggle with food provision in the months to come. In December 1203, when they were once again outside the city walls, expelled by the Byzantines, who, just in case, had removed swiped all traces of food in the area, a great famine once again struck the crusaders. Earlier, the Venetians used hunger to force the crusaders to obedience. Now, it was the other way around. The Byzantines used the same method to chase away the Venetians and crusaders de-

${ }^{9}$ Villehardouin, chapter 91-94, 143; Clari, chapter XXXII.

10 Villehardouin, chapter 113.

11 Villehardouin, chapter 131: "Il a isles ci prés, que vos poez veoir de ci, qui sont habites de gens et laborees de blez et de vïandes et d'autres biens: alons iki prendre port, et recuillons les blés et vïandes del païs; et quant nos avrons les vïandes recuillies, alomes, devant la ville et fesond ce que Nostre Sires nos avra porveü."; chapters 135, 137.

12 Villehardouin, chapter 165: “Ne n'avoient pooir que il porcaçassent vïande .iiii. arbalestees loing de l'ost; et il en avoient mult poi, se et de farine non et de bacons; et de cel avoient des chevaus que on lor ocioit; et sachies que il n'avoient vïande comunelment a tote l'ost trois semaines."

${ }^{13}$ Villehardouin, chapter 181: “...si se desarmerent, qui erent mult las et travaillié; et poi mangierent, et poi burent, car poi avoint de vïande; chapter 191: Ensi sejornerent en pais et repos en grant plenté de bones vïandes." 
manding political and financial compensation from the city. Around the beginning of 1204, Robert de Clari claimed that no one helped them, and the only merchant ship, potentially carrying food which could feed them, was burned by Greeks. The Byzantines also occasionally started fires in order to destroy the Venetian fleet and devastate the outskirts ${ }^{14}$. In the crusaders' camp everything was extremely expensive: sestier of wine cost 12-15 sou, chicken 20 sou, and an egg 2 sou. The only product that was reasonably priced, and it was in abundance, were crackers ${ }^{15}$. This is the only information on pricing that appears in the publications. The measurement unit, sestier is derived from the Latin term sestertius. It was a petty coin used in the Roman times. In this context, it is a volume unit, about 1.1 litres, since, out of analogy, in the times of the emperor Augustus, one sestertius was the equivalent of the price of a main meal, or the price of $1.1 \mathrm{li}$ tres of wine. Sou was worth a $1 / 20$ of a solid silver coin.

After the second conquest of the city, in April 1204, the enraged masses of crusaders robbed the city, but for the first time since their stay in Zadar, people could eat until they were full, especially on May 16, 1204, after the feast celebrating the coronation of Baldwin of Flanders as the Emperor ${ }^{16}$.

Unfortunately, even careful and detailed analysis of the abovementioned pieces of the two texts yields very small results. This analysis is only a small contribution in an attempt to create, however incomplete, a picture of provisioning during the Crusades.

Zdzisław Pentek - a professor at the Adam Mickiewicz University, in the Institute of Balkan Studies Institute. His areas of expertise are the history of crusades, the Arabic world (from the $6^{\text {th }}$ to $13^{\text {th }}$ century), Byzantium, and the Balkan Peninsula in the Middle Ages.

14 The article on fires and devastations was written by Th. F., Madden, The fires of the fourth crusade in Constantinople 1203-1204: a damage assessment, Byzantinische Zeitschrift, 84 / 1991-1992 [1993], p. 72-93.

15 Clari, chapter LX: “Et le kiertés estoit si grans en l'ost que on i vendoit un sestier de vin .sij. saus, .xiiij. saus., .xv. saus tele eure fu, et une geline .xx. suas, et un oef. ij. deniers; mais du bescuit n'i avoit il mie tele kierté, ains en avoient auques a leur ost maintenir une pieche."

${ }^{16}$ Clari, chapter XCVII. 